\title{
Muslim diversity: Islam and local tradition in Java and Sulawesi, Indonesia
}

\author{
Muhamad Ali
}

Religious Studies Department, University of California, Riverside, USA

E-mail:muhamadali74@yahoo.com

\begin{abstract}
Based on some historical and anthropological accounts, this article examines a dynamic interplay between Islam and local tradition in Indonesia with special reference to Java and Sulawesi. It explains how local Muslims differed in their interpretation and application of Islam. It looks at processes of religious change as a world religion interacts with local forces. The "localization" of Islam was a constant feature in the expansion of Islam beyond the Arab homeland, including Southeast Asia. Based on the framework of 'practical Islam', rather than 'normative Islam', and on the framework of both accommodation and conflict between shari'ah and adat as a whole system, rather than as separate entities, it provides a greater variety of Islamic beliefs and experiences. Comparatively, Javanese people have been more diverse than Sulawesi people in terms of religious spectrum; Muslims in Java have incorporated animism, Hinduism, Buddhism, and Islam into their culture system. Stories about the nine saints show how early Islamic preachers sought to accommodate Islam with local traditions. In Sulawesi, Dato ri Bandang and the other teachers, representing the elite aristocracy who attempted to Islamize the kingdoms and the people alike and Syeikh Yusuf, representing a strict kind of Islam, show diversity but tends to suggest a less diverse picture, when compared to Java. Despite internal diversity in Java as well as in Sulawesi, Java has remained more open and tolerant with cultural diversity, whereas Sulawesi has increasingly become more legalistic.
\end{abstract}


Berdasarkan kajian sejarah dan antropologis, artikel ini membahas hubungan dinamis antara Islam dan budaya lokal di Indonesia dengan rujukan khusus pada Jawa dan Sulawesi. Artikel ini menjelaskan bagaimana orang Islam lokal berbeda dalam memahami dan menerapkan Islam. Artikel ini melihat proses-proses perubahan keagamaan ketika agama dunia bergumul dengan kekuatan-kekuatan lokal. Lokalisasi Islam adalah ciri tetap dalam penyebaran Islam melampaui tanah Arab, termasuk Asia Tenggara. Berdasarkan kerangka "Islam sebagaimana yang dipraktekkan" ('Islam praktikal'), bukan 'Islam normatif' dan kerangka akomodasi dan konflik antara syari'ah dan adat sebagai sistem yang menyeluruh, bukan realitas yang terpisah, artikel ini menawarkan kemajemukan kepercayaan dan pengalaman Islam. Secara komparatif, orang-orang Jawa lebih majemuk daripada orang-orang Sulawesi dalam hal spektrum keagamaan. Orang-orang Islam di Jawa memasukkan animism, agama Hindu dan Buddha, dan Islam kedalam sistem budaya mereka. Cerita-cerita tentang wali songo menunjukkan bagaimana penyebar-penyebar Islam awal berusaha mengakomodasi Islam dengan budayabudaya lokal. Di Sulawesi, Dato ri Bandang dan guru-guru lainnya, yang mewakili kaum bangsawan yang berusaha melakukan pengislaman kerajaan-kerajaan dan orang-orang, dan Syeikh Yusuf yang mewakili kaum yang lebih tegas, menunjukkan keragaman keagamaan, namun tidak semajemuk di Jawa. Meskipun ada kemajemukan di Jawa dan di Sulawesi, Jawa tampaknya lebih terbuka dan toleran dengan perbedaan budaya, sedangkan Sulawesi menunjukkan kecenderungan yang legalistik. Namun demikian, keagamaan jangan dipahami bersifat statis, liner, lengkap, dan selesai.

Keywords: Adat (tradition); Sharia; Ethnicity; Practical Islam; Localization

\section{Introduction}

The question of the relationships between Islam and tradition has occupied both Western and non-Western scholars as Islam spreads all over the world and enters into various different local traditions and cultures. It appears that there has been an increasing awareness among scholars that Islam has been so diverse that one can no longer view it as a monolithic entity. As we become aware of facing the risk of oversim- 
plification of such diversity, it is still our challenge to better understand the history and realities of the Muslim world and to recognize the diversity and the many faces of Islam. This approach lessens the risk of creating self-fulfilling prophecies that augur the battle of the West against a radical Islam or a clash of civilizations. ${ }^{1}$ The West has an ideal vantage point for appreciating the aspirations of many in the Muslim world, including Indonesia, as part of Southeast Asia, which is located in the periphery, with the Middle East as the centre.

Based on historical and anthropological sources, this paper sets out to examine a dynamic interplay between Islam and local tradition in Indonesia with special reference to Java and Sulawesi. This aims to understand how local Muslims differed in their interpretation and application of Islam within particular context, as well as how they shared common features. By focusing on the practical application of Islam in Java and Sulawesi, this paper hopes to contribute to an understanding of some of the processes of religious change as a world religion interacts with local forces. The "localization" of Islam was a constant feature in the expansion of Islam beyond the Arab homeland, and therefore one would expect this same development in Southeast Asia. ${ }^{2}$

\footnotetext{
${ }^{1}$ See Samuel Huntington, "The Clash of Civilizations?", Foreign Affairs, Volume 72, Number 3 (November 1993), 22-49.

2 'Localization' signifies a process of selective appropriation and localization of materials to make local sense of therefore familiar and valuable what was originally 'foreign'. It should not be supposed, however, that local cultural systems remain unchanged when they had localized foreign materials. In Indonesia, Islam is one of the foreign cultures. See O.W. Wolters, "Towards Defining Southeast Asian History", in O.W. Wolters, History, Culture, and Region in Southeast Asian Perspectives, Ithaca \& Singapore: Cornell Southeast Asia Program Publications \& The Institute of Southeast Asian Studies, 1999, 55-7; O.W.Wolters, "Southeast Asia as A Southeast Asian Field of Study", Indonesia, 58 (October 1994), 1-18.
} 


\section{Islam and tradition: some conceptual frameworks}

In Islam, sharia means path of God. Sharia has been associated with Islamic law, which is not always the case; Sharia consists of various aspects of life: not only law, but also belief and morality. ${ }^{3}$ Adat (Arabic: 'ādah) can be defined as tradition or custom. ${ }^{4}$ In theory, adat can be regarded as part of sharia. Adat can be legitimate or justified as a code of conduct for a Muslim (al-'ādah Muhkamah) as long as it does not contradict with Islamic principles. The prophet Muhammad himself has an open mind toward those pre-Islamic Arab customs that he did not regard as endangering the establishment of his new religion. ${ }^{5}$ The problem mostly lies in interpretation and it is in this area that we can talk about the diversity of application of the sharia in local customs (adat).

The first conceptual framework to help understand the relationships between Islam and tradition would be 'practical Islam', as opposed to 'idealistic or normative Islam'. 'Practical' refers to how ordinary people (peasants, merchants, mystics, priests, scholars, etc) order and articulate categories, symbols, and the relations between them in the pursuit of comprehending, expressing, and formulating social practice

\footnotetext{
${ }^{3}$ The term sharia is only mentioned once in the Koran, which, according to Yusuf Ali, means laws or rules of practical conduct. Every prophet was revealed their own version of law. There is some debate over whether Islamic law as sharia is similar to that as fiqh (jurisprudence). Abdullah Yusuf Ali, The Meaning of Holy Qur'an, Maryland: Amana Publications, 1989, 263; Wael B. Hallaq, A History of Islamic Legal Theories: An Introduction to Sunni Usul al-Fiqh, Cambridge: Cambridge University Press, 1999, 232-3.

${ }^{4}$ Custom is the real historical continuity, while tradition is related to the past. For Benhard Dahm, tradition is "an adherence to values that have been influential in shaping cultural traditions of a given people. Giving them a sense of identity which they try to defend if it is challenged." See Benhard Dahm, "The Role of Tradition in Historical Developments in Southeast Asia", Archipel, Volume II, Number 57, Paris: Association Archipel, 1999, 17.

${ }^{5}$ See Khalil 'Abd al-Karim, al-Judhūr al-Tärïkhiyya li al-Sharì'a al-Islāmiyya, Cairo: Sinā li alNashr, 1990, 15-9, 85-9; Wael B.Hallaq, A History of Islamic Legal Theories: An Introduction to Sunni Usul al-Fiqh, Cambridge: Cambridge University Press, 1997, 12.
} 
and experience. ${ }^{6}$ Therefore, when one writes or talks about Islam, he or she should be aware of what he or she means by Islam: whether it is Islam as being practiced by whoever calling himself or herself a Muslim (thus, 'practical Islam') or it is what should be believed or done by a Muslim (normative Islam). The former is generally historical or anthropological, while the latter is more theological or philosophical.

A number of Western scholars studying Islam and Muslim societies have tended to argue, for example, that Java is "more or less Islamic" than it was in the past.7 For example, while Geertz in 1950s argued that Java was in general less Islamic than the centre of Islam, Middle East, or even when compared to Morocco, Woodward and Hefner held that Javanese Islam is more complete than Geertz would have thought. ${ }^{8}$ It is problematic to make categorizations while not explaining what constitutes 'Islamic' and 'un-Islamic'. Javanese Muslims for example may immediately question the judgment that their Islam is not truly Islamic. Even when some Muslims are syncretistic or eclectic they may regard themselves as Islamic. In this regard, to solve such conceptual problems, as a French philosopher Claude Lévi-Strauss has pointed out, we need to understand that "words are instruments that

\footnotetext{
${ }^{6}$ See E.R. Leach, "Introduction", in E.R. Leach (ed.), Dialectic in Practical Religion, Cambridge: Cambridge University Press, 1968, 1-2; Roy F.Ellen, "Social Theory, Ethnography, and the Understanding of Practical Islam in South-East Asia", in M.B.Hooker (ed.), Islam in Southeast Asia, Leiden: E.J. Brill, 1983, 64-9.

${ }^{7}$ Although Donald K. Emmerson realized that "Islam is the hardest for Western scholars to empathize and get inside of", he or any non-Muslims, I would argue, can actually study Muslim beliefs and practices in an objective, scientific manner. Donald K. Emmerson, "Issues in Southeast Asian History: Room for Interpretation- A Review Article", Journal of Asian Studies, Volume XL, Number 1 (November 1980), 59.

${ }^{8}$ See Robert W. Hefner, "Islam in an Era of Nation-states: Politics and Religious Renewal in Muslim Southeast Asia", in Robert W. Hefner \& Patricia Horvatic (eds.), Islam in an Era of Nationstates: Politics and Religious Renewal in Muslim Southeast Asia, Honolulu: University of Hawaii Press, 1997, 3-31.
} 
people are free to adapt to any use, provided they make clear their intentions." ${ }^{\prime \prime}$ In the social sciences, there are wide and frequent variations in the meaning of simplest words, according to the thought that uses or informs them. In other words, what we mean by 'Islam' should be made clear from the outset.

Being aware of such conceptual problems when using vocabularies and categories has a further implication on our understanding about the extent to which Islam has had an impact on the traditions of local areas in Indonesia. Some scholars hold that Islam has played an insignificant role in the lives of local peoples. A Dutch scholar, J.C. van Leur, for example, argues that along with other world religions and foreign cultures, Islam has exerted weak influence. "They did not bring any fundamental changes in any part of Indonesian social and political order", J.C. van Leur claims, "The sheen of the world religions and foreign cultural forms is a thin and flaking glaze; underneath it the whole of the old indigenous forms has continued to exist -with many sorts of gradations appearing, of course, according to cultural level". ${ }^{10}$

By focusing on 'practical Islam', instead of 'normative Islam', one can be relatively more objective. As an historian of Southeast Asian Islam, William R. Roff, would argue, scholars need to focus on how a Muslim actually perceives and practices Islam and how a particular context influences a particular perception or practice. Roff, for example, provides us with the following questions: "How do we understand the nature, impulse and dynamic of Muslim social and political action? What are the relationships, direct or dialectical, between the prescriptions and requirements of Islamic belief, socially reproduced

\footnotetext{
${ }^{9}$ Quoted in Fernand Braudel, "Changing Vocabulary", A History of Civilizations, New York: Penguin Books, 1995, 3.

10 J.C. van Leur, Indonesian Trade and Society: Essays in Asian Social and Economic History, The Hague: Van Hoeve, 1955, 169.
} 
(of 'being Muslim', in short), and the economic, political, and social circumstances of the lives of actual Muslims?"11 This would mean studying Islam as historical reality; partly as a text-based world religion, i.e. as a de-contextualized global reality, and partly as localized, contextualized cases of so-called Islamic beliefs and practices. This attempt is to accommodate descriptions of a wide variety of beliefs and actions labeled Islamic by people themselves. Muslim diversity is therefore the starting point. We need analyses about how their stories are constructed, how they become real to those who think them to be true, and how they sometimes change. As a consequence, we shall see internal pluralism, ethnic diversity, and multiple discourses. ${ }^{12}$

The second framework which may be useful would be to look at Islam not simply in a binary opposition (such as traditionalism-modernism, legalism-mysticism, etc) as if there is no grey area or something in between. Certainly binary categorization is helpful in providing some comprehension, but one should bear in mind that categorization serves as simplification, rather than as a perfect mirror of realities. The fact has been always more complex than the binary opposition between for example syncretically mystical (whether animist, Indic, Javanese, or Sufistic) and scripturally orthodox forms (legalistic). ${ }^{13}$ Such variants of religiosity as santri and abangan for Javanese Islam as explored by Clifford Geertz, for example, should not be understood as being separate, static, and irreconcilable. ${ }^{14}$ Or, to give another ex-

${ }^{11}$ William R. Roff (ed.), Islam and the Political Economy of Meaning, London: Croom Helm, 1987, 1-2; William R. Roff, "Afterword: The Comparative Study of Muslim Societies", in Leif Manger (ed.), Muslim Diversity: Local Islam in Global Context, Richmond: Curzon Press, 1999, 246-247.

12 See Leif Manger, "Muslim Diversity: Local Islam in Global Context", 1-3.

${ }^{13}$ See William R. Roff, "Islam Obscured? Some Reflections on Studies of Islam and Society in Southeast Asia", L'Islam en Indonesie, I, Archipel, 29, Paris: Association Archipel, 1985, 8.

${ }^{14}$ Clifford Geertz, The Religion of Java, Illinois: The Free Press of Glencoe, 1960, 4-7. 
ample, the variants of 'folk tradition' and 'great tradition' as advocated by Ernest Gellner cannot simply mean that Hinduism has been always a folk religion, while Islam always a great tradition and that Islam of the peasants for example is less modernized or less sophisticated than Islam of the scholars. ${ }^{15}$

A more specific conceptual framework in looking at the relationships between Islam and tradition would be either accommodation or conflict. An anthropologist Roy F. Ellen, for example, has proposed a tool of analysis by which Islam and tradition can be better understood. For Ellen, 'accommodation' reflects the integration of Islam and tradition through a traditional cosmological framework, and organized according to a variety of interconnecting symbolic oppositions, mediated in a manner which gives the appearance of harmony. 'Conflict', on the other hand, neither implies a clear separation between the content of Islam and the content of tradition, cross-culturally identical meanings, or a necessary conflict between the two. "Contradictions", Roy F. Ellen goes on to say, "are often minimized in practice, remain latent and potential than actual, or are resolved through symbolic casuistry, but at best this accommodation is partial and temporary, the product of specific circumstances." 16 This conceptual framework can be compared with Weber's observation that while in theory sharia is rigid and inflexible, it is in practice always unstable and flexible. ${ }^{17}$

\footnotetext{
${ }^{15}$ Gellner observed that Hinduism is a folk religion, whereas Islam can manifest itself in a folk or a great tradition. "Islamic great tradition is modernisable, and the operation can be presented, not as an innovation or concession to outsiders, but rather as the continuation and completion of an old dialogue within Islam between ...Holy Law and mere human custom...." Ernest Gellner, Muslim Society, Cambridge: Cambridge University Press, 1981, 4-5.

${ }^{16}$ Roy F.Ellen, "Social Theory, Ethnography, and the Understanding of Practical Islam in South-East Asia", in M.B.Hooker (ed.), Islam in Southeast Asia, Leiden: E.J. Brill, 1983, 64-9.

17 Max Weber, Economy and Society: an Outline of Interpretative Sociology, vol.2, edited by G.Roth and C.Wittich, New York: Bedminster Press, 1968, 821. There are however some cases where the application of shari'a is hardly flexible when an issue is regarded by Muslims as being
} 
An Indonesian historian Taufik Abdullah proposed that Islam and tradition should not be seen as separate and contradicting entities. The tensions between sharia and adat should be comprehended in a dialogical, dialectical way. Adat and sharia are parts of the whole cultural system of Muslim societies. In Minangkabau, Sumatera, for example, Islam as religion and adat as tradition are compatible worldviews and complement each other, "not as water and milk, but as water and oil in milk". Islam can serve as tradition itself. Abdullah further argues, "A conceptual, operational scheme should incorporate all relevant phenomena and should be applied in historical development. Islam-tradition conflict should be rethought."18 Snouck Hurgronje's approach that religion governs only god-human relations, while tradition deals with social relations is no longer helpful in understanding the complexity inherent in Islam and tradition. Therefore, Abdullah argues, one should not see the conflict as between the ideal and the actual, but between social realities approaching the ideal. ${ }^{19}$ Abdullah seems to correspond to David J. Banks, working on Malaysian Islam, who holds that Islam can serve as a progressive source of adat and to Daniel Lev who argues that Islam has provided a universal law for Indonesia even before Dutch political authority was completed and that Islamic legal concepts and vocabularies had to supply most of the basic notion of law (hukum), justice (adi), rights (hak) and tradition (adat) itself. ${ }^{20}$ These sugges-

related to the fundamental belief (Arabic: 'aqìdah), not merely to social relationship (mu'āmalāt). See for example Muhamad Ali, "Fatwas on Inter-faith Marriage in Indonesia", Studia Islamika: Indonesian Journal for Islamic Studies, Volume 9, Number 3 (2002), 3-31.

${ }^{18}$ Taufik Abdullah, "Adat dan Islam: Suatu Tinjauan tentang Konflik di Minangkabau", in Taufik Abdullah (ed.), Sejarah dan Masyarakat: Lintasan Historis Islam di Indonesia, Jakarta: Pustaka Firdaus, 1987, 104-27.

${ }^{19}$ Taufik Abdullah, "Adat dan Islam: Suatu Tinjauan tentang Konflik di Minangkabau", 127.

${ }^{20}$ David J. Banks, "Islam and Inheritance in Malaya: Culture Conflict or Islamic Revolution?", American Ethnologist, III, 586 as quoted in William R. Roff, "Islam Obscured?", 12; Daniel S. Lev, 
tions support the interpretation that religions represent cultural systems, which are both influenced by processes of social change and are themselves able to affect them. ${ }^{21}$

We have thus far discussed some of the frameworks to resolve conceptual problems when studying Islam and tradition. Bearing this in mind, we will now look at two local cases: Java and Sulawesi respectively.

\section{Islamization, sharia and adat in Java}

The history of Islamization in Java, either as a whole or in any of its parts, is not an unchecked, linear, uniform process, but rather one that "waxed and waned, that took its strength from an irregular pattern of pulses over centuries".22 An historian M.C. Ricklefs proposed three main stages in the conversion of the Javanese to Islam. The first stage, from $14^{\text {th }}$ to $18^{\text {th }}$ century, was marked by tolerant Hindu-Buddhist religion, followed by the conversion to Islam by traders and rulers through the traditional elite. According to Ricklefs, in this period, Islam brought few important changes in religious life. But the Javanese Muslims of the coast became more legalistic than those in the interior for the former experienced more contacts with outside world, including shariaoriented preachers, while the latter had been familiar with Hindu-Buddha civilization. In the interior, subjects most probably became Muslim because their lord was. By the $16^{\text {th }}$ century Sufi (mystical) teachings

Islamic Courts in Indonesia: A Study in the Political Bases of Legal Institutions, Berkeley: University of California Press, 1972, 4-5.

${ }^{21}$ Clifford Geertz,"Religion As A Cultural System", in Clifford Geertz, The Interpretation of Cultures, New York: Basic Books, Inc.,Publishers, 1973, 87-125; Bassam Tibi, trans. Clare Krojzl, Islam and the Cultural Accommodation of Social Change, Boulder, San Francisco \& Oxford: Westview Press, 1990, 1-5.

${ }^{22}$ A.H. Johns, "From Coastal Settlement to Islamic School and City: Islamization in Sumatera, the Malay Peninsula, and Java", Hamdard Islamicus, Volume IV, Number 4 (1981), 5. 
had become known in which Islam became a source of supernatural energy. A Javanese chronicle, Babad Tanah Javi, for example, says, "At that time many Javanese wished to be taught the religion of the prophet and to learn supernatural powers and invincibility." 23 Thus, in this period, syncretism became more dominant in the interior than in the coastal Java.

In the $16^{\text {th }}$ century, when the Portuguese controlled Malaka, the central power in Java proper was still Hindu-Javanese Majapahit, although its downfall was at hand. Muslim propagation penetrated into Hindu-Javanese centre. A Muslim who would settle himself amongst non-Muslims would operate as cell, which is inclined to grow. This cellbuilding was able to go its way undisturbed among the tolerant HinduJavanese. The supremacy was transferred from Majapahit to Demak, marking only a political shift from a Hindu-Buddhist dominance to an Islamic one. ${ }^{24}$ Culturally, however, Hindu-Buddhism, Animism, Islam, and Christianity coexisted if not influenced each other.

Within inner Java, the combined forces of peasant folk religion and the high culture of Javanese Hindu-Buddhism (or Siva-Buddhism) predisposed recipients of the new faith to adopt its theosophical rather than its legalistic emphases. The greatness of an Indianized past was subsequently diminished by Islam and by Christian missionaries whose rudimentary rule-book understanding of Islam led them to see it as deficient in performance in $19^{\text {th }}$ century Java and prone to mystical and superstitious excesses. Yet on the other hand, the Kingdom of Mataram, having been Islamized from the coastal areas in the $16^{\text {th }}$ and $17^{\text {th }}$

\footnotetext{
${ }^{23}$ Merle C. Ricklefs, "Six Centuries of Islamization in Java", in Nehemia Levtzion (ed.), Conversion to Islam, New York: Holmes \& Meier Publishers, Inc., 1979, 109.

${ }^{24}$ R.A. Kern, "The Propagation of Islam in the Indonesian-Malay Archipelago" in Alijah Gordon (ed.), The Propagation of Islam in the Indonesian-Malay Archipelago, Kuala Lumpur: Malaysian Sociological Research Institute, 2001, 50-54.
} 
centuries, showed a more legalistic orientation. ${ }^{25}$

The well known early carriers of Islam to Java were the wali sanga or the nine saints during the $15^{\text {th }}$ and $16^{\text {th }}$ centuries. They represented diversity in Javanese Islam for each saint had uniqueness in teaching and character. Some were more mystical or less legalistic than others. For example, one of the nine saints, Sunan Kalijaga, demonstrated a tolerant, accommodating character in his preaching by using wayang the Hindu-Budhist shadow puppet. Sunan Kalijaga represented "a symbol, a materialized idea...the bridge between two high civilizations, two historical epochs, and two great religions, the meaningful link between a world of god-kings and ritual priests." ${ }^{\prime 26}$ On the other hand, Syeikh Siti Jennar represented a liberal mystic Islam, which was then condemned as a heresy by the other eight saints. 'Islam Mutihan' (white Islam) was then recognized as referring to the eight saints, whereas 'Islam Abangan' (red Islam) to syncretistic Syeikh Siti Jennar.

Accordingly, an Indonesian anthropologist, Koentjaraningrat, divided Javanese religion into two: a syncretistic Agama Jawi (or kejawen), which combines pre-Hindu, Hindu, and Islamic elements and Agama Islam Santri, which attempts to purify the pre-Islamic elements. However, Koentjaraningrat claimed, in contrast with Geertz (1960) and Anderson (1972), the penetration of Islam in interior Java was not without resistance from local Javanese, including from Hindu Mataram kingdom. In addition, Koentjaranigrat made a distinction between Islam in the coastal areas of Java (pesisir) and that in the interior (pedalaman). For the most part, Koentjaraningrat argues, the former seemed to be more orthodox than the latter. ${ }^{27}$

\footnotetext{
25 Roff, "Islam Obscured?", 21-22.

26 Roff, "Islam Obscured?", 27.

27 Koentjaranigrat, Kebudayaan Jawa, Jakarta: PN Balai Pustaka, 1984, 310-18.
} 
The second stage of Islamization in Java (the nineteenth century) witnessed colonialism and Islamic revivalism. ${ }^{28}$ After the opening of the Suez Canal in 1869, the number of Indonesian hajjis (pilgrims to Mecca) rose significantly, intensifying Middle East-Indonesian networks. Consequently, divisions along religious lines emerged: a firm or orthodox Muslim and a less firm Muslim. ${ }^{29}$ At the third stage, the twentieth century, Javanese Muslims seemed to become more diversified. Ricklefs then developed religious variants derived from Geertz models: priyayisantri (elite-firm Muslim), wong cilik-abangan-kolot (traditional lower class, little committed to Islam), the priyayi-abangan kolot/modern (upperclass, less firm) and wong cilik-santri-kolot (lower-class, firm, traditional). In the 1955 election, the Indonesian Nationalist Party (priyayi-abangan kolot/modern with wong cilik-abangan-kolot) gained around 32 percent of the votes in Java. The Masyumi (priyayi-santri-modern) gained 11 percent. The Islamic traditional organization, the Nahdlatul Ulama (wong cilik-santri-kolot) won about 30 percent. ${ }^{30}$ The Indonesian Communist Party (wong cilik-abangan-kolot/modern) gained 27 percent. These results suggest the extent to which abangan and santrikolot ideas still dominated the Javanese population. ${ }^{31}$ However, since the nineteenth century the Islamic reform movement in the Middle East had an impact on Javanese Islam. The Muhammadiyah, a modernist, reform-oriented organization, has sought to make better Mus-

${ }^{28}$ Revivalism brings out the idea of returning to the golden past and a desire to revive what is antiquated. Chandra Muzaffar, "Islamic Resurgence: A Global View", in Taufik Abdullah \& Sharon Siddique (eds.), Islam and Society in Southeast Asia, Singapore: Institute of Southeast Asian Studies, 1986, 6.

${ }^{29}$ Ricklefs, "Six Centuries", 112-117.

30 The Nahdlatul Ulama was established in 1926 by Hashim Ash'ari, originally as a reaction to the Muhammadiyyah's modernism, although it experienced a dynamic change.

${ }^{31}$ Ricklefs, "Six Centuries", 120. 
lims of the Javanese. ${ }^{32}$ In a progressively more secular society, of the various available versions of Islam, the modernist will probably have the greatest appeal to the elite and in the long run to lower social levels as well. ${ }^{33}$

As can be seen above, since Java was deeply influenced by HinduBuddhist and Javanese culture, the process of Islamization had experienced tensions unrecognized elsewhere in Indonesia and even in the rest of the Muslim world. Despite the diversity, the eight saints and most Muslims embraced Sunni Islam, following the medieval Sufi alGhazali, except Sunan Gunung Jati, who is said to be a follower of moderate Shiite Islam. Javanese Muslims have attempted to deal with the tensions between Islam and pre-existing Hindu-Buddhist and animist beliefs and practices. For the majority, sharia and adat were thought to be in harmony. ${ }^{34}$ At the same time, generally speaking, tolerance made it easier for the Javanese people to adopt different cultural systems at once. ${ }^{35}$ The stories about the nine saints and subsequent local preachers would suggest that syncretism of Javanese people became the norm, rather than the exception. ${ }^{36}$

Nonetheless, as we have discussed in the previous section, the binary opposition between orthodoxy and syncretism reveals only parts of the realities. In Geertz's presentation, one gains the im-

\footnotetext{
32 The Muhammadiyyah was found in 1912 in Yogyakarta by KH Ahmad Dahlan, inspired by Muhammad Abduh's reformism. Muhammadiyyah and Nahdlatul Ulama are the two largest religious organizations in Java and in Indonesia in general. Regarding a comparative study of Islamization see Nehemia Levtzion, "Toward a Comparative Study of Islamization", in Nehemia Levtzion (ed.), Conversion to Islam, New York: Holmes \& Meier Publishers, Inc., 1979, 21.

${ }^{33}$ Nehemia Levtzion, "Toward a Comparative Study of Islamization",126-127.

${ }^{34}$ See Widji Saksono, Mengislamkan Tanah Jawa: Telaah Atas Metode Dakwah Walisongo, Bandung: Penerbit Mizan, 1995, 230-3.

${ }^{35}$ See Ismawati, "Budaya dan Kepercayaan Jawa pra-Islam", in H.M. Darori Amin (ed.), Islam dan Kebudayaan Jawa, Yogyakarta: Gama Media, 2000, 13.

36 M.Darori Amin, "Sinkretisme dalam Masyarakat Jawa", 85.
} 
pression that practitioners of the three religious variants (santri, abangan, prijaji) inhabit separate worlds and each is consistent in his or her separate identity. ${ }^{37}$ In contrast with Geertz, Andrew Beatty observed that much of rural Java has been populated by heterogeneous communities and individuals; and many of them are neither clearly santri nor abangan but something in between. Thus, there can be found in Banyuwangi the "rival langgars", "young zealots", "crusty conservatives", "hajis", and "skeptics", who, nonetheless, "all are willing to make concessions in order to maintain social harmony in the neighborhood."138

In Java, 'grey areas' in religious experience seem to have developed in such a way that Islamic elements were blended with preIslamic ones. For example, one major feature of Javanese religion has been the slametan. "At the center of the whole Javanese religious system", Geertz observed, "lies a simple, formal, undramatic, almost furtive little ritual: the slametan... the Javanese version of what is perhaps the world's most common religious ritual, the communal feast." ${ }^{\prime 39}$ The slametan has played an important role in Javanese Islam. ${ }^{40}$ Geertz regards slametan as the abangan rituals, whereas Woodward views it as justified by Islamic texts. Woodward argues, "The religious goals of the slametan are rooted in local interpretations of the Sufi theory of mystical union, and the modes of ritual action it employs are based on practices attributed to the prophet Muhammad (Hadith)." ${ }^{41}$

\footnotetext{
${ }^{37}$ Clifford Geertz, The Religion of Java, Illinois: The Free Press of Glencoe, 1960, 1-7.

${ }^{38}$ Andrew Beatty, Varieties of Javanese Religion: An Anthropological Account, Cambridge: Cambridge University Press, 1999, 115, 156.

${ }^{39}$ Clifford Geertz, The Religion of Java, 11.

${ }^{40}$ Robert W. Hefner, Hindu Javanese: Tengger Tradition and Islam, Princeton \& New Jersey: Princeton University Press, 1985, 105

${ }^{41}$ Mark R.Woodward, Islam in Java: Normative Piety and Mysticism in the Sultanate of Yogyakarta, Tucson: The University of Arizona Press, 1989, 52.
} 
In contemporary Java, the predication of Islam seems to be more complicated due to a greater variety of variables involved, including nationalism, modernization, democratization, and globalization. ${ }^{42}$ The impacts of these developments can be clearly discerned. For example, Batasan, a village in Java, witnessed the transformation of both Islam and tradition. Rural people became Muslim in a more overtly Islamic symbolic framework. The Islamic local leaders (mostly from the Islamic party, Partai Persatuan Pembangunan) and the local officials (a dominant government party, Golkar) in the village competed for influence. The Islamic party gained influence in certain religious areas, especially rituals, while the former had an influence on secular affairs such as dress code, roads, schools, and other administrative affairs. Local traditions were increasingly removed not only by Islamic movements but also by nationalistic norms. National policies, including floating mass, party politics and Nahdlatul Ulama's withdrawal from practical politics, influenced the way Muslims identified themselves in relation to Islam and locality. Nahdlatul Ulama (NU) exerted a greater influence in rural areas than Muhammadiyah, but the contrast between rural and urban weakened because of urbanization or greater contact. The traditional communal feasts (slametan, tahlilan, or resepsi) became part of Javanese cultural life. Some animistic elements in these feasts were increasingly removed, while people, who still wanted to do animistic rituals like offering to the dead or certain sacred sites, practiced the ritual privately. As a consequence, "Monotheistic and animistic

${ }^{42}$ See for example, Robert W. Hefner, "Islamization and Democratization in Indonesia" in Robert W. Hefner \& Patricia Horvatic (eds.), Islam in an Era of Nation-states: Politics and Religious Renewal in Muslim Southeast Asia, Honolulu: University of Hawaii Press, 1997, 75-127; Dale f.Eickelman \& Jon W.Anderson (eds), New Media in the Muslim World: The Emerging Public Sphere, Bloomington \& Indianapolis: Indiana University Press, 1999; Johan Meuleman (ed.), Islam in the Era of Globalization: Muslim Attitudes towards Modernity and Identity, London: RoutledgeCurzon, 2002. 
interpretations of the slametan potentially co-occur on every single occasion," Eldar Braten observed. ${ }^{43}$

In another village, Tegalreso, social politics of New Order government (1966-1998) also had a great impact on religious life. As a result of floating mass policy where political parties were not allowed to establish offices at the district levels, meaning de-politization of rural communities which in turn reduced the risk of religious polarization, santriabangan distinction became blurred. From 1945 independence to 1965, the presence of political parties influenced religious life. Nationalism, communism, and Islam gained their own followers in Tegalreso. In the New Order period, orthodoxy became strengthened. Almost all people in Tegalreso became Muslim. Some of local people said, "In the last twenty years, Tegalreso has now become more 'Islamic' than previously. ${ }^{44}$

The meaning of Islamization of a social or ethnic group "not as a single act of conversion but a long process toward greater conformity and orthodoxy" can only satisfy the Islamic reformists, such as the Muhammadiyah. Islamization thus means a struggle to bring adat elements that are regarded as contradictory to Islam into conformity with Islam. For traditionalists, represented by the Nahdlatul Ulama, Islamization signifies a struggle for a greater compromise between sharia and adat. The Muhammadiyah regards Islamization as a struggle to maintain, in the face of this adaptive flexibility, the identity of Islam not just as religion in general but as the particular directives communicated by God to mankind through the preemptory prophecies of Muhammad. The Nahdlatul Ulama, on the other hand, defines Islamization as an

\footnotetext{
${ }^{43}$ Eldar Braten, "To Color, Not Oppose: Spreading Islam in Rural Java", in Leif Manger (ed.), Muslim Diversity, 150-71.

${ }^{44}$ M. Bambang Pranowo, "Partai Politik dan Islamisasi di Pedesaan Jawa", in Saiful Muzani, Pembangunan dan Kebangkitan Islam di Asia Tenggara, Jakarta: LP3ES, 1993, 178-95.
} 
effort to adapt a universal, in theory standardized and essentially unchangeable, and unusually well-integrated system of ritual and belief to realities of local, even individual, moral, and metaphysical perception. ${ }^{45}$ Yet, both movements regard Islamization as a gradual process. ${ }^{46}$

Now we may ask: Why was Islam adopted in Java while pre-Islamic elements remained present if not became Islamized? The great triumph of Islam was its ability, within certain limits, to tolerate numerous pre-Muslim beliefs and practices. This was in turn due to the fact that the corpus of Islamic law and tradition, the sharia, allows for some local interpretation. Islam became the religion of nearly all Javanese in the period after the fourteenth century largely because it adapted successfully to the main configurations of pre-existing Javanese religion. It did not fundamentally alter the mystical theme; it gave it yet another vocabulary, a new range of explanations and illustrations, a new set of powerful ritual phrases. And it was tolerant. It gave greater richness to Javanese religion without requiring the complete abandonment of older ideas. Thus Java came to be a Muslim society, but one in which Islam was only a part of the vast cultural heritage. Woodward, however, holds that the acceptability of Islam in Java was owing to Sufistic nature of Islam that first came to Java. As Woodward observed in Yogyakarta, "Javanese Islam is unique not because it retains aspects of pre-Muslim culture and religion but because of the degree to which Sufi concepts of sainthood, the mystical path, and the perfection of man are employed in the formulation of an imperial cult." ${ }^{\prime 47}$

\footnotetext{
${ }^{45}$ Clifford Geertz, Islam Observed: Religious Developments in Marocco and Indonesia, New Haven \& London: Yale University Press, 1968, 14-5.

${ }_{46}^{46}$ Muslim Abdurrahman, "Beri-Islam secara Kultural", Republika, 27 June 2003.

47 Mark R. Woodward, Islam in Java: Normative Piety and Mysticism in the Sultanate of Yogyakarta, Tucson: The University of Arizona Press, 1989, 242.
} 


\section{Islamization, shari'a and adat in Sulawesi}

The indigenous belief of the Sulawesi islands (eastern part of Indonesia) was tribal animism. Every sub-ethnic group had its own belief. In Bugis and Makassar, the notion of god and creation existed in the indigenous belief. In local religion, besides god of creation, there was a cycle of beliefs which centered around Karaeng-lowé (great teacher) who gave happiness and sadness, life and death. ${ }^{48}$ Toani Tolotang, Patuntung, and Aluk Todolo were amongst the main indigenous beliefs commonly called animism. Related to animism, shamanism (mediation between human beings and spirits) was also recognized. ${ }^{49}$ Between the period of animism and Islam there was hardly any Hindu-Buddhist influence. In this regard, Sulawesi and Java are different, which in turn affected the nature of Islamization in Sulawesi in such a way that local people in Sulawesi are either to embrace Islam more strictly or to remain animist, while not adopting Hindu-Buddhist elements, such as the Ramayana-Mahabharata epic. ${ }^{50}$

Many superstitions (tahayul) have taken root in Sulawesi, but they centered around non-Bugis areas, where the belief in I La Galigo which features several godly couples living in heaven and in the underworld and population of earth by sending their offspring and the latter's servants there as respective ancestors to the nobility and commoners. ${ }^{51}$ Some manuscripts evince elements of pre-Islamic belief systems, for instance in invoking the name of the spirit of the tree, but using Islamic utterances to strengthen the spell. Another manuscript advises the

48 Waldemar Stohr \& Piet Zoetmulder, Les Religions d'Indonesia, Paris: Payot, 1968, 116-7.

49 Tim Penulis, Sejarah Kebudayaan Sulawesi, Jakarta: Departemen Pendidikan dan Kebudayaan, 1995, 30-5.

${ }^{50}$ Muslim Abdurrahman, "Ber-Islam Secara Kultural", Republika, 27 June 2003

${ }^{51}$ Christian Pelras, "Religion, Tradition, and the Dynamics of Islamization of South Sulawesi", Archipel, 29, (Paris: Association Archipel, 1985, 108. 
wood-copper to call the 'inhabitant of the forest': "Wahai (hello) spirit, give me your wood. I want to make it a house post. Then utter salam (Peace be with you). When you proceed to feel timber, call out 'My name is Adam, the tree is called Ali, Allah ta'ala (God is sublime)."52 A blending of Islamic and pre-Islamic beliefs remains apparent in contemporary communities. Fetishism or belief in sacred objects such as royal regalia, the Koran, and the banners of communities are smeared with blood (ceraq) to magically strengthen them. In the Makassarese Story of Syeikh Yusuf, the writer declared, "Whoever from the ummat of Nabi Muhammad who after me can listen to the stories of Tusalamaka [Syeikh Yusuf] whether they read it, store it in their house, of firmly believe it in their heart, clearly all their sins will be forgiven."153

In Sulawesi, Islam was first embraced by aristocracy. In the year 1603 , it is reported, "the King and his sister embrace Islam". The conversion of the kings resulted in the entire realm accepting Islam. Islam made its entry without violence, but the further propagation took a violent way when Goa waged a number of wars to force the small realm of South Sulawesi to embrace Islam. Some populations were still pagan or animist. Generally speaking, in Sulawesi (except Makassar and Bugis), Ternate laid the foundation of Islamization and Goa proceeded to build on this foundation. Islam became the religion of the kingdom since the lord had converted. The conversion of the population was neither the object of choice nor of coercion; it was a simple affair of education. In another case, a Muslim would have accepted

\footnotetext{
${ }^{52}$ Kathryn Robinson, "Traditions of House-Building in South Sulawesi", in Kathryn Robinson \& Mukhlis Paeni, Living Through Histories: Culture, History, and Social Life in South Sulawesi, Canberra: The Australian National University and the National Archives of Indonesia, 1998, 180.

${ }^{53}$ Manyambeang, "Lontaraq Riwayagna Tuanta Salamaka", 187, in William Cummings, Making Blood White: Historical Transformations in Early Modern Makassar, Honolulu: University of Hawaii Press, 2002, 54.
} 
both the old belief and Islam. In the early modern period, kings (sul$\tan$ ) often served as a problem-solver when there was a conflict between adat and sharia. ${ }^{54}$ Consequently, in Sulawesi, Islam quickly became not only the dominant religion but also an essential element of their civilization. ${ }^{55}$ Politically, an Islamic based ideology was adopted by aristocratic power, which was new to South Sulawesi albeit not new in the Malay world, being influenced by Persian idea of king as a shadow of God, as can be read in the Mahkota Segala Raja or Taj al-Salatin, written in 1603 in Aceh by Syeikh Bukhari of Johor (now part of Malaysia) as an attempt to get rid of pagan or animist beliefs and practices. ${ }^{56}$ Islamization networks were dominated by kings, despite the important roles played Muslim traders from Java, Banten, and Malaka.

By the seventeenth century, three preachers: Dato Tallua, Dato ri Bandang, and Dato ri Pattimang (Dato Sulaiman), who came from Minangkabau, Sumatera, under instruction of Acehnese king, had succeeded to convert the major part of South Sulawesi. The main role of these three preachers must have been to contrive a way of solving the apparent incompatibility between Islam and traditional order. For

\footnotetext{
${ }^{54}$ Abu Hamid, "Sistem Nilai Islam dalam Budaya Bugis-Makassar", in Aswab Mahasin et. al. (eds.), Ruh Islam dalam Budaya Bangsa: Aneka Budaya Nusantara, Jakarta: Yayasan Festival Istiqlal, 1996, 171-2.

${ }^{55}$ R.A. Kern, "The Propagation of Islam in the Indonesian-Malay Archipelago" in Alijah Gordon (ed.), The Propagation of Islam, 72-80; Henri Chamber-Loir, "Dato ri Bandang. Legendes de I'Islamisation de la region de Célèbes-Sud", Archipel 29, Paris: Association Archipel, 1985, 155.

${ }^{56}$ Chamber-Loir writes, "L'acceptation de la novella religion toutefois créa en meme temps un lien nouveau d'egalité entre le vainqueur et le vaincu." Pelras also writes, "Ce n'est sans doute pas un hazard si c'est a cette époque que ses habitants choisissent d'adherer a une religion mondiale : christianisme d'abord, puis faute d'un appui reel des Portugais, Islam qui deviandra rapidement l'un des elements essentiels de leur culture." Leonard Y. Andaya, The Kingdom of Johor 1641-1728: Economic and Political Developments, Kuala Lumpur, Oxford University Press, 1975; Christian Pelras, "Religion, Tradition, and the Dynamics of Islamization in South Sulawesi", Archipel 29, Paris: Association Archipel, 1985, 125; Chamber-Loir, "Datu ri Bandang", 139; Leonard Y.Andaya, The Heritage of Arung Palaka, La Haye: VKI, 1981, 35.
} 
example, according to I La Galigo (epic poem) episodes, Dato Sulaiman taught the doctrine of tauhid (Oneness of God) by using Bugis beliefs about the One God (Déwata Séuwaé) and about Sawérigading. ${ }^{57}$ But, in the late seventeenth century, Syeikh Yusuf (1626-1699) of Makassar, who was a disciple of Nuruddin al-Raniri of Aceh, a mystic from Aceh who reputed the wah\}daniyyah (union with God) of Hamzah Fansuri, attempted to purify South Sulawesi Islam from pagan remnants and improper behavior. ${ }^{58}$ Syeikh Yusuf is said to have represented a strict, legalistic Islam, as opposed to an Islam friendly with local tradition. This means that Islamization process took place not without tension amongst mystical preachers. Despite the fact that they studied in Mecca, they constituted different versions of Islam and this had an impact upon the kind of Islam they taught in South Sulawesi. In South Sulawesi, the tarekats (Sufi orders) bear witness to the development of two kinds of mysticism: a purifying one and a syncretic one. While it is true that the kind of popular Islam in the early period of Islamization in Makassar was mystical, one should not deny the increasing domination of the legalistic, purifying Islam, as represented by Syeikh Yusuf from Makassar. In another island, Bima, for example, the followers of Abdul Basir are said to have been more concerned with external (i.e. sharia-oriented or legalistic) aspect of Islam, whereas those of Pua' Janggo were mostly centered in interiority or mystics. The legal school adopted in Sulawesi, as in most of Southeast Asian areas, was and is still Sunni-Shafi'i. ${ }^{59}$

57 Leonard Y.Andaya, The Heritage of Arung Palaka, 117, 120.

${ }^{58}$ A.Qadir Gassing, "Tuangta Salamaka Syekh Yusuf Tajul Khalwati", in Andi Rasdiyanah Amir (ed.), Bugis-Makassar dalam Peta Islamisasi Indonesia, Ujung Pandang: IAIN Alauddin, 1982, 39-48. Concerning the doctrinal debate between Al-Raniri and Hamzah al-Fansuri See Syed Muhammad Naquib Al-Attas, Raniri and The Wujudiyyah of $17^{\text {th }}$ Century Aceh, Singapore: Malaysia Printers Ltd., 1966, 18-56.

${ }^{59}$ Christian Perlas, "Religion, Tradition, and the Dynamics of Islamization in South Sulawesi", 112; On Islam in Bima, see Michael Hitchcock, Islam and Identity in Eastern Indonesia, Hull: University of Hull Press,1988. 
Another way in dealing with sharia and adat in pre-modern Sulawesi was the official separation between the religious and the secular, although cultural overlapping did occur. In Luwu and Wajo, Dato Sulaiman taught fundamental obligations of Islam and some elements of theology and designated 6 religious functionaries ( 2 khatib, 2 bilal, 1 pangulu, and 1 amil). There was a separation between secular administration (adat) and religious administration (sharia). Dato ri Bandang cumulated the functions of kadi (judge) and of amil (administrator).Dato ri Bandang entered Gowa with the Karaeng for converting the population. A mosque was built and the people were taught to pray five times a day, Friday prayer, recitation of the Koran, mysticism (tașawwuf), logics (mantiq), and the contact with God (munājāt). Dato ri Bandang added three more fundamentals of Islam: purification (istinja), profession of faith (shahādah), and impurity (junnu). Some rituals were important, including taräwịh (evening prayer at the month of Ramadhan), nisf sha'ban (prayer at mid-month of sha'ban). According to Dato ri Bandang, the Karaeng is the representative of God on earth and must be just and pious and pray on Friday. ${ }^{60}$

The main language of Islamic predication in Sulawesi was Malay, which was then translated into local vernaculars. Culturally, spiritually, commercially and politically, Makassar and its allies in South Sulawesi became part of the Islamic community (ummah), part of Turkey, Mongol, as well as Aceh, the Islamic powerful kingdom in Western Indonesia. Javanese traders also travelled to Makassar. ${ }^{61}$ The Javanese traders who traveled to the Moluccas would have passed Sulawesi (South Sulawesi, Makassar, and Bugis). Bugis and Makassar peoples then contributed to the Islamization of North Sulawesi and other part

\footnotetext{
60 Henry Chamber-Loir, "Dato ri Bandang", 143-50.

${ }^{61}$ Henry Chamber-Loir, "Dato ri Bandang", 156, 161.
} 
of eastern Indonesia. ${ }^{62}$ As Philip D.Curtin has pointed out, in Makassar, Islam became a form of modernization, although the people attempted to make the language of Islam more suited to local needs. ${ }^{63}$

A new phase was marked by the coming of preachers of the reformist, orthodox Muhammadiyah to South Sulawesi in 1928. The Muhammadiyah introduced class-based schools and modern, secular sciences. In 1975, the members did not exceed 50,000 (out of 6 millions), but their sympathizers are believed far more numerous and their influence is still stronger. The Muhammadiyah has been concerned with establishing schools, mosques, hospitals, charities, as well as with religious reform to distinguish the obligatory from the provisional 'ibādah (ritual obligations) and the orthodox from the heretic beliefs and practices. ${ }^{64}$

In addition, after the World War II, several modern institutions were built, including one founded by the disciples of Haji As'ad (a Mecca born and ulama (scholar) of Bugis descent), the most prominent being the Darul Dakwah wa al-Irsyad (or Al-Irsyad), which in 1970s had established 1.200 schools all over South Sulawesi as well as in Kalimantan and Sumatra. Muhammadiyah and Al-Irsyad are said to have represented reformism and orthodoxy. Apart from Muhammadiyah and AlIrsyad, a number organization such as Sarikat Islam, Nahdatussyafiiyah, Persatuan Islam, and Partai Arab Indonesia, played important roles in anti-colonial movements. ${ }^{65}$

\footnotetext{
${ }^{62}$ Waldemar Stohr \& Piet Zoetmulder, Les Religions d'Indonesia, 317.

${ }^{63}$ Philip D. Curtin, Cross-cultural Trade in World History, Cambridge: Cambridge University Press, 1984, 162.

${ }^{64}$ Ibrahim Polontalo, Muhammadiyah di Sulawesi Utara 1928-1990, Gorontalo: Karya Dunia Fikir, 1995, 3-4.

${ }^{65}$ See Yayasan 23 January 1942 \& IKIP Negeri Manado Cabang Gorontalo, Perjuangan Rakyat Di Daerah Gorontalo, Gorontalo: PT Gobel Dharma Nusantara, 1982, 34-37.
} 
At present, the northern part of Sulawesi is Muslim, with the exception of the Minahasa, where only 25,000 are Muslim, mostly foreigners or their descendents, while in Bolaang-Mongondow, the Protestant mission is making progress. The southern part is entirely Muslim, a few pagans live there, and there are a few hundred Christians. For the island as a whole, the ratio of Muslims, Christians and pagans in round figures would be as follows: 3,350,000 Muslims, 485,000 Christians, and 300,000 pagans. ${ }^{66}$

In Makassar, Islam in the lowlands has differed from that in the highlands. This difference may be explained by the fact that it was not until 1911 after Gowa's surrender to the Dutch that Islam entered the highlands. The first preacher there was Sulaeman Daeng Bunding, a member of the high nobility of Gowa, appointed by the Dutch colonial administration. The difference lay on language, material culture, and indigenous belief. Patuntung, a person who strives to bring his or her behavior into conformity with tradition, was the indigenous believer in the highlands. As Islam came, the highlanders recognized a variety of deities, so they understood such Islamic terms as Allah, Malaikat and Jinn in their traditional conceptions of spirit. Islam was localized and Islamic idioms were regarded as part of their traditional heritage. ${ }^{67}$

Muslim reformists, especially members of the Muhammadiyah, would regard many of the old beliefs as contradictory to Islam. Muslim reformists criticized the practice because they saw heirlooms (for example) as the pre-Islamic basis of the nobility's power and regarded

${ }^{66}$ R.A. Kern, "The Propagation of Islam in the Indonesian-Malay Archipelago" in Alijah Gordon (ed.), The Propagation of Islam, 80-81.

${ }^{67}$ Martin Rossler, "Islamization and the Reshaping of Identities in Rural South Sulawesi" in Robert W.Hefner and Patricia Horvatich (eds.), Islam in an Era of Nation-States: Politics and Religious Renewal in Muslim Southeast Asia, Honolulu: University of Hawaii Press, 1997, 277, 284. 
the nobility as incompatible with Islam, which they saw as emphasizing equality among men. With the outbreak of the war for independence in 1945, the Muhammadiyah became one of the main forces struggling against the Dutch administration, which was still supported by influential nobles from Gowa and neighboring kingdoms. A few years later, the Darul Islam rebellion (1950-1965) broke out and, under the leadership of the charismatic Qahar Muzakkar, challenged the region's power structure even further. Significantly, however, many of Qahar's followers were associated with the Muhammadiyah, which shared the rebel's anti-colonialist and anti-feudal attitudes. ${ }^{68}$

Muslim reformism seems to gain a greater adherence. The contemporary elite and popular slogan saying that "adat should be based on sharia, and sharia on the Holy Koran" (adat bersendikan sharia dan sharia bersendikan kitabullah) and contemporary movements towards the constitutionalization of Islamic law in Sulawesi suggest that orthodoxy has become more apparent in Sulawesi. For example, a villager Nasir in 1984 made the following observation: "The old belief is irreconcilable with true religion. How can we village people ever become modern when even our leaders practice the old belief? They make such offerings to the ancestors so that the harvest can be rich. No one can hear what the priest is saying during the offerings. Why is he whispering? In Islam, it is different. Our prayers are pronounced loudly and clearly, the words are Arabic, and they are taken from the holy Koran." 69

${ }^{68}$ Patricia Horvatich (eds.), Islam in an Era of Nation-States: Politics and Religious Renewal in Muslim Southeast Asia, 276-277.

69 Patricia Horvatich (eds.), Islam in an Era of Nation-States: Politics and Religious Renewal in Muslim Southeast Asia, 282. 


\section{Conclusion}

This paper has discussed some of the conceptual frameworks which can be useful in studying the relationships between Islam and tradition in context and has examined some of the historical and contemporary developments of local Islam in Java and Sulawesi, Indonesia. Basing on the frameworks of 'practical Islam', rather than 'normative Islam' and of both accommodation and conflict between sharia and adat as a whole system, rather than as separate entities, this paper has attempted to provide a greater variety of Islamic beliefs and experiences.

As a common feature, Islam became the dominant force in Java and Sulawesi but did not completely obliterate the indigenous beliefs and practices. The adoption of Islam by local peoples does not necessarily mean that they have to give up all of their old traditions. Acculturation seems to be the norm rather than the exception in the Islamization process in Java and Sulawesi. Despite their adoption of Islam and many associated cultural elements, the local people are both selfconfessedly Muslim (being part of the Islamic community, ummah) and loyal to their local identity. In this regard, I agree with Eickelman who holds that pre-existing cultural and religious patterns, together with local configurations of social and economic power, influence the ways in which universalistic texts, including the Koran and the Hadith, are interpreted. ${ }^{70} \mathrm{I}$ also share the suggestion that local communities have been able to synthesize elements of different origins and reject others. We can call this a process of selective adaptation in which local peoples are not simply passive receptors.

70 D.Eickelman, "The Study of Islam in Local Contexts", Contributions to Asian Studies 17 (1982), 1-16. 
Comparatively, Javanese people have been more diverse than Sulawesi people in terms of religious spectrum; Muslims in Java have incorporated animism, Hindu-Buddhism, and Islam into their culture system. Stories about the nine saints show how early Islamic preachers sought to accommodate Islam with local traditions, including HinduBuddhist elements. In Sulawesi, Dato ri Bandang and the other teachers, representing the elite aristocracy who attempted to Islamize the kingdoms and the people alike and Syeikh Yusuf, representing a strict kind of Islam, tend to suggest a less diverse picture, when compared to Java. Despite internal diversity in Java as well as in Sulawesi, Java has remained more open and tolerant with cultural diversity, whereas Sulawesi has increasingly become more legalistic. This has been so partly because it is the reformist Muhammadiyah that dominated religious institutions and cultures in Sulawesi, while in Java, the accommodationist Nahdlatul Ulama and the modernist Muhammadiyah have equally attempted to gain their religious influence.

However, religiosity should not be understood as something that is static, linear, complete, and final. Most Muslims, orthodox, syncretistic, or anything else, seem to have regarded Islamization as a gradual process. By the same token, ethnic identity is by no means static and final. Having explored some of the historical transformations of Islam and tradition, we can understand that ethnicity is "a set of social relationships and processes by which cultural differences are communi-

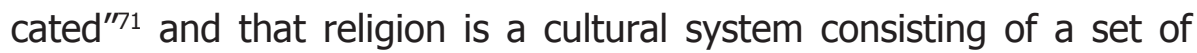
norms and practices towards which Muslims attempt to approach. Local tradition itself is not unchanging so we can talk about the transfor-

71 T.H. Erickson, "The Cultural Contexts of Ethnic Differences", Man, Volume 26, Number 1 (1991) , 127 in Michael Hitchcock, Islam and Identity in Eastern Indonesia, Hull: The University of Hull Press, 1996, 10-11. 
mation of tradition which is influenced among other things by modernization and development. ${ }^{72}$ Consequently, old identity boundaries often became blurred. Certain adat rituals or sharia rituals, such as the slametan, may have continued to be performed but they may have lost their former functional meaning. In other words, meaning changes according to time and place.

\section{Bibliography}

Abdullah, Taufik, "Adat dan Islam: Suatu Tinjauan tentang Konflik di Minangkabau", in Taufik Abdullah (ed.), Sejarah dan Masyarakat: Lintasan Historis Islam di Indonesia. Jakarta: Pustaka Firdaus, 1987. Abdurrahman, Muslim, "Ber-Islam Secara Kultural", Republika, 27 June 2003.

Ali, Abdullah Yusuf. The Meaning of Holy Qur'an. Maryland: Amana Publications, 1989.

Ali, Muhamad, "Fatwas on Inter-faith Marriage in Indonesia", Studia Islamika: Indonesian Journal for Islamic Studies, Volume 9, Number 3 (2002).

Amin, M. Darori, "Sinkretisme dalam Masyarakat Jawa", in H.M. Darori Amin (ed.), Islam dan Kebudayaan Jawa. Yogyakarta: Gama Media, 2000.

Andaya, Leonard Y. The Heritage of Arung Palaka. La Haye: VKI, 1981.

Attas, Syed Muhammad Naquib Al-. Raniri and The Wujudiyyah of $17^{\text {th }}$ Century Aceh. Singapore: Malaysia Printers Ltd., 1966.

72 See Bernhard Dahm, "The Role of Tradition in Historical Development", Archipel, II, 57, Paris: Association Archipel, 1999, 20. 
Beatty, Andrew. Varieties of Javanese Religion: An Anthropological Account. Cambridge: Cambridge University Press, 1999.

Braten, Eldar, "To Color, Not Oppose: Spreading Islam in Rural Java", in Leif Manger (ed.), Muslim Diversity: Local Islam in Global Context. Richmond: Curzon Press, 1999.

Braudel, Fernand, "Changing Vocabulary", A History of Civilizations. New York: Penguin Books, 1995.

Curtin, Philip D. Cross-cultural Trade in World History. Cambridge: Cambridge University Press, 1984.

Dahm, Bernhard, "The Role of Tradition in Historical Development in Southeast Asia", Archipel, II, 57, Paris: Association Archipel, 1999. Eickelman, Dale F., "The Study of Islam in Local Contexts", Contributions to Asian Studies 17 (1982).

Eickelman, Dale F. \& Jon W.Anderson (eds.). New Media in the Muslim World: The Emerging Public Sphere. Bloomington \& Indianapolis: Indiana University Press, 1999.

Ellen, Roy F., "Social Theory, Ethnography, and the Understanding of Practical Islam in South-East Asia", in M.B.Hooker (ed.). Islam in Southeast Asia. Leiden: E.J. Brill, 1983.

Emmerson, Donald K., "Issues in Southeast Asian History: Room for Interpretation- A Review Article", Journal of Asian Studies, Volume XL, Number 1 (November 1980).

Erickson, T.H., "The Cultural Contexts of Ethnic Differences", Man, Volume 26,Number 1 (1991) in Michael Hitchcock, Islam and Identity in Eastern Indonesia. Hull: The University of Hull Press, 1996. Gassing, A. Qadir, "Tuangta Salamaka Syekh Yusuf Tajul Khalwati", in Andi Rasdiyanah Amir (ed.), Bugis-Makassar dalam Peta Islamisasi Indonesia. Ujung Pandang: IAIN Alauddin, 1982. 
Geertz, Clifford. The Religion of Java. Illinois: The Free Press of Glencoe, 1960.

Geertz, Clifford. Islam Observed: Religious Developments in Morocco and Indonesia. New Haven \& London: Yale University Press, 1968. Geertz, Clifford, "Religion As A Cultural System", in Clifford Geertz, The Interpretation of Cultures. New York: Basic Books, Inc.,Publishers, 1973.

Gellner, Ernest. Muslim Society. Cambridge: Cambridge University Press, 1981.

Hallaq, Wael B. A History of Islamic Legal Theories: An Introduction to Sunni Usul al-Fiqh. Cambridge: Cambridge University Press, 1997. Hamid, Abu, "Sistem Nilai Islam dalam Budaya Bugis-Makassar", in Aswab Mahasin et. al. (eds.), Ruh Islam dalam Budaya Bangsa: Aneka Budaya Nusantara. Jakarta: Yayasan Festival Istiqlal, 1996.

Hefner, Robert W. Hindu Javanese: Tengger Tradition and Islam. Princeton \& New Jersey: Princeton University Press, 1985.

Hefner, Robert W, "Islam in an Era of Nation-states: Politics and Religious Renewal in Muslim Southeast Asia", in Robert W. Hefner \& Patricia Horvatic (eds.), Islam in an Era of Nation-states: Politics and Religious Renewal in Muslim Southeast Asia. Honolulu: University of Hawaii Press, 1997.

Hefner, Robert W, "Islamization and Democratization in Indonesia" in Robert W. Hefner \& Patricia Horvatic (eds.), Islam in an Era of Nation-states: Politics and Religious Renewal in Muslim Southeast Asia. Honolulu: University of Hawaii Press, 1997.

Hitchcock, Michael. Islam and Identity in Eastern Indonesia. Hull: University of Hull Press,1988. 
Huntington, Samuel, "The Clash of Civilizations?", Foreign Affairs, Volume 72, Number 3 (November 1993).

Ismawati, "Budaya dan Kepercayaan Jawa pra-Islam", in H.M. Darori Amin (ed.), Islam dan Kebudayaan Jawa (Yogyakarta: Gama Media, 2000.

Johns, A.H., "From Coastal Settlement to Islamic school and city: Islamization in Sumatera, the Malay Peninsula, and Java", Hamdard Islamicus, Volume IV, Number 4 (1981).

Karim, Khalil 'Abd al-. Al-Judhūr al-Tärikhiyya li al-Sharī'a al-Islāmiyya. Cairo: Sina li al-Nashr, 1990.

Kern, R.A., "The Propagation of Islam in the Indonesian-Malay Archipelago" in Alijah Gordon (ed.), The Propagation of Islam in the Indonesian-Malay Archipelago. Kuala Lumpur: Malaysian Sociological Research Institute, 2001.

Koentjaranigrat. Kebudayaan Jawa. Jakarta: PN Balai Pustaka, 1984. Leach, E.R., "Introduction", in E.R. Leach (ed.), Dialectic in Practical Religion. Cambridge: Cambridge University Press, 1968.

Leur, J.C. van. Indonesian Trade and Society: Essays in Asian Social and Economic History. The Hague: Van Hoeve, 1955.

Lev, Daniel S. Islamic Courts in Indonesia: A Study in the Political Bases of Legal Institutions. Berkeley: University of California Press, 1972. Levtzion, Nehemian, "Toward a Comparative Study of Islamization", in Nehemia Levtzion (ed.), Conversion to Islam. New York: Holmes \& Meier Publishers, Inc., 1979.

Loir, Henri Chamber-, "Dato ri Bandang. Legendes de I'Tslamisation de la region de Célèbes-Sud", Archipel 29, Paris: Association Archipel, 1985. 
Manger, Leif, "Muslim Diversity: Local Islam in Global Context", in Leif Manger (ed.), Muslim Diversity: Local Islam in Global Context (Richmond: Curzon Press, 1999).

Manyambeang, "Lontaraq Riwayagna Tuanta Salamaka", 187, in William Cummings, Making Blood White: Historical Transformations in Early Modern Makassar. Honolulu: University of Hawaii Press, 2002.

Meuleman, Johan (ed.). Islam in the Era of Globalization: Muslim Attitudes towards Modernity and Identity. London: RoutledgeCurzon, 2002.

Muzaffar, Chandra, "Islamic Resurgence: A Global View", in Taufik Abdullah \& Sharon Siddique (eds.), Islam and Society in Southeast Asia. Singapore: Institute of Southeast Asian Studies, 1986.

Pelras, Christian, "Religion, Tradition, and the Dynamics of Islamization of South Sulawesi", Archipel, 29, Paris: Association Archipel, 1985.

Polontalo, Ibrahim. Muhammadiyah di Sulawesi Utara 1928-1990. Gorontalo: Karya Dunia Fikir, 1995.

Pranowo, M. Bambang, "Partai Politik dan Islamisasi di Pedesaan Jawa", in Saiful Muzani, Pembangunan dan Kebangkitan Islam di Asia Tenggara. Jakarta: LP3ES, 1993.

Ricklefs, Merle C., "Six Centuries of Islamization in Java", in Nehemia Levtzion (ed.). Conversion to Islam. New York: Holmes \& Meier Publishers, Inc., 1979.

Robinson, Kathryn, "Traditions of House-Building in South Sulawesi", in Kathryn Robinson \& Mukhlis Paeni. Living Through Histories: Culture, History, and Social Life in South Sulawesi. Canberra: The Australian National University and the National Archives of Indonesia, 1998. 
Hefner, Robert W. (ed.). Islam and the Political Economy of Meaning. London: Croom Helm, 1987.

Hefner, Robert W., "Islam Obscured? Some Reflections on Studies of Islam and Society in Southeast Asia", L'Islam en Indonesie, I, Archipel, 29, Paris: Association Archipel, 1985.

Hefner, Robert W., "Afterword: The Comparative Study of Muslim Societies", in Leif Manger (ed.), Muslim Diversity: Local Islam in Global Context (Richmond: Curzon Press, 1999.

Rossler, Martin, "Islamization and the Reshaping of Identities in Rural South Sulawesi" in Robert W.Hefner and Patricia Horvatich (eds.), Islam in an Era of Nation-States: Politics and Religious Renewal in Muslim Southeast Asia. Honolulu: University of Hawaii Press, 1997. Saksono, Widji. Mengislamkan Tanah Jawa: Telaah Atas Metode Dakwah Walisongo. Bandung: Penerbit Mizan, 1995.

Stohr, Waldemar, \& Piet Zoetmulder. Les Religions d'Indonesia. Paris: Payot, 1968.

Tibi, Bassam. trans. Clare Krojzl. Islam and the Cultural Accommodation of Social Change. Boulder, San Francisco \& Oxford: Westview Press, 1990.

Tim Penulis. Sejarah Kebudayaan Sulawesi. Jakarta: Departemen Pendidikan dan Kebudayaan, 1995.

Weber, Max. Economy and Society: an Outline of Interpretative Sociology, vol.2, edited by G.Roth and C.Wittich, New York: Bedminster Press, 1968.

Wolters, O.W. "Southeast Asia as A Southeast Asian Field of Study", Indonesia, 58 (October 1994). 
Wolters, O.W., "Towards Defining Southeast Asian History", in O.W. Wolters, History. Culture, and Region in Southeast Asian Perspectives. Ithaca \& Singapore: Cornell Southeast Asia Program Publications \& The Institute of Southeast Asian Studies, 1999.

Woodward, Mark R. Islam in Java: Normative Piety and Mysticism in the Sultanate of Yogyakarta. Tucson: The University of Arizona Press, 1989.

Yayasan 23 January 1942 \& IKIP Negeri Manado Cabang Gorontalo. Perjuangan Rakyat Di Daerah Gorontalo. Gorontalo: PT Gobel Dharma Nusantara, 1982. 